\title{
Broadening notions of 'missing persons' to increase social inclusion, public empathy and healing: Considering the case of children missing through adoption
}

\section{Susan Gair (1 ${ }^{\text {st }}$ Author)}

James Cook University

Sharon Moloney (2 ${ }^{\text {nd }}$ Author)

James Cook University

\section{Abstract}

A missing person is defined as someone whose whereabouts are unknown and fears exist for the safety and welfare of that person. Families of a reported missing person experience many emotions including unresolved grief and ambiguous loss as they manage day to day with the traumatising reality of their loved one being psychologically present but physically absent. While not diminishing that recognised trauma, there are families with missing members who do not fit the usual social script of 'missing persons', and as a result, these families may gain different levels of public acknowledgement, support and empathy. An example is the trauma and loss felt by birth parents, tinged with a painful but enduring optimism of a reunion with their child, which might be better understood through a 'missing person' lens. Drawing on the personal narrative of the second author and past research of the first author, we seek to illuminate the ongoing trauma and ambiguous loss felt when a child is missing through adoption. We argue for a broader notion of 'missing persons' that could benefit families who remain excluded from social support and 
empathic understanding of their grief.

Keywords: Missing persons, adoption, unresolved grief, ambiguous loss

\section{Introduction}

"Missingness becomes of concern when someone is missed" Clark, (2006, p.42).

People with an identified missing family member face the traumatising reality that the whereabouts of a loved one is unknown. The person is psychologically present but physically absent in family members' lives. This type of ambiguous loss has been described as the most difficult loss to bear (Boss, 1999a). While not diminishing that felt trauma, similarities can be drawn to families of children missing through known circumstances, for example, the trauma, grief and loss felt by parents in past forced and closed adoptions. Equally, family members of the Stolen Generation (Ekermann, Dowd, Chong, Nixon, Gray \& Johnson, 2006), and British child migrants (Humphreys, 1995) describe 'missing children' and an enduring hope of reunion. Although adopted children do not fit the social script of 'missing persons', birth parents of adopted children could be considered to experience many of the same thoughts, distress, fears and hope felt by families of reported missing persons. Our aim in this article is to broaden readers' notions of 'missing' children. To this end, the inclusion of a first person narrative in this article is intended to illuminate the lived experience of one mother with a child missing through adoption. While public and institutional support seems evident when children and adults are reported missing, the accepted 'master narrative' of past child adoption may have left many parents feeling unsupported and socially excluded, a factor which compounds their trauma, grief and loss. For professionals supporting families who have endured adoption experiences, the 'missing person lens' may provide a useful analogy to engender empathy for what their clients have experienced.

\section{Background}

In Australia, one legal definition of a missing person is "someone whose whereabouts is unknown and there are serious concerns for their safety and welfare" (National Missing Persons Unit, 1999, cited in James, Anderson \& Putt, 2008, pp. 4- 
5). Payne (1995) described a missing person as absent from their network of personal and social relationships, and other persons are searching for them; "you go missing and are experienced by others as missing" (p. 356). Public concern and empathy for parents of missing children is common as unrelated individuals imagine their own distress and trauma should they be forced to face what often is said to be a parent's greatest fear. Research has identified that families and friends of missing persons can suffer significant long-term health and mental health problems as a result of the ongoing trauma, and that some comfort is found in demonstrated community concern (Fravel \& Boss, 1992; Henderson \& Henderson, 1998; Missing People, 2012).

A contrasting scenario regarding public empathy for missing children appears to be thosefamilies whose children are physically missing and their absence is deeply grieved, but their whereabouts may have a legal explanation, for example, in the case of closed and forced adoptions. Adopted children normally are not conceptualised as 'missing' even though they are absent from the lives of their biological parents. Similarly, the Stolen Generation, British child migrants and Forgotten Australians commonly were not perceived as missing persons, except perhaps by their families, even when their families described their children as being 'taken', or 'stolen' (Ekermann, et al., 2008, p. 76; Hancox, 2011). Mounting literature in Australia, the United Kingdom and elsewhere provides evidence that the subsequent unresolved, ambiguous loss resulted in ongoing, episodic grief, trauma and serious mental health issues, including suicide (Askren \& Bloom, 1999; Carabas \& Harter, 2005; Edwards \& Read, 1989; Human Rights and Equal Opportunity Commission, 1997; Cole, 2008; $1^{\text {st }}$ Author, 2008; Higgins, 2010; Humphreys, 1995; McNiece, 2006). Despite parents' suffering, such stories remained comparatively unspoken, excluded and hidden from view.

Social exclusion is said to exist where persons have limited ability to access appropriate information and services, and limited social or economic participation in their community. According to Meininger (2010) the problem of social exclusion results from a core conflict between the reality of some people's lives and the normative framework of their society. Some persons or groups are not heard or valued as legitimate participants in their society, their stories are excluded, and they are hindered from actioning their own personal agency and resources. Perpetuation of such exclusion is advanced through social reproduction and legitimised meta- 
narratives (Bourdieu, 1977; Chamberlain, 2011; Commonwealth of Australia, DEEWR, 2009; Hancox, 2011; Lareau, \& McNamara Horvat, 1999). Meta-narratives limit, exclude and stereotype those persons whose experiences or reality falls outside the "pre-scribed" social norms (Meininger, 2010, p. 196; Swartz, 1992).

Meta-narratives are comprehensive, normative frameworks that purport to explain human experience, thus playing a role in legitimising prescribed explanations and behaviours. Meta-narratives often are imbued with subordination and dominance. Within meta-narratives, some individuals are perceived to be "outside the boundary in which moral values, rules and considerations of fairness apply" (Opotow, 1990 , p. 1). For whatever reasons, these stories are considered undeserving and therefore are excluded from the accepted social narrative $\left(1^{\text {st }} \& 2^{\text {nd }}\right.$ Author, 2013). Swartz (1992, p. 341) spoke of "master scripting" that renders some groups' experiences invisible. In recognition of the power of meta-narratives to constrain, subjugate, exclude and render invisible, Meininger (2010, p. 197) urged moral reflection that enables a "better story" to emerge, one more socially inclusive, socially just, liberating and accepting of experiences that might not fit the stereotype. Such lived experiences have potential to create connections between people because they can "take the exceptional from its situation of rejection in which it has been pushed by...general opinion" (Meininger, p. 195), and provoke its re-conceptualisation from a previously unconsidered perspective. In this article, we recognise the contested nature of the term 'birth mother' and where possible we have used the terms 'mother, father or parents', except in instances where the meaning would be unclear.

\section{The institution of closed adoption}

A recent Senate Community Affairs Committee Inquiry into the Commonwealth Contribution to Former Forced Adoption Policies and Practices (Senate Inquiry) called for evidence of the Commonwealth's contribution to former forced adoption policies and practices (The Senate Community Affairs References Committee, 2012). The term 'forced adoption' referred to adoptions where there was a failure to obtain a fully informed, freely given consent from the mother (and the father) before an adoption proceeded. Many children were lost from the lives of their mothers, fathers, grandparents and extended families. The Senate Inquiry received hundreds of submissions confirming that forced adoptions were condoned in Australia. While not all adoptions were forced, there were extensive testimonies of past trauma, grief 
and loss that prevailed over time (The Senate Community Affairs References Committee, 2012).

From an historical perspective, the institution of adoption evolved from the end of the $19^{\text {th }}$ century to the mid $20^{\text {th }}$ century to become an accepted answer to several social problems: illegitimate children, unmarried mothers and infertility. Like Britain and the United States, adoption in Australia became a closed legal process that extinguished past parental ties and authorised new (adoptive) parents to rear the child (O'Halloran, 2006; Watson \& Granvold, 2008). Legally, adoption was a confidential, irrevocable process where babies deemed to be 'unwanted' were placed predominantly but not exclusively with childless couples and the State was relieved of any burden of care.

From the 1950s, unmarried mothers were strongly encouraged by professionals and their own families to relinquish their baby to preserve the social and moral values of the era ( $1^{\text {st }}$ Author, 2008; Inglis, 1984; Shawyer, 1979). Religious and welfare bodies upheld the notion that the solution to the problem of illegitimate babies was their adoption by a married woman who was deemed 'fit' to mother ( $1^{\text {st }}$ Author, 2008; O'Halloran, 2006). In many cases, while signed paperwork existed, mothers whose children were lost to them through closed adoptions recount traumatic stories of being coerced to sign (The Senate Community Affairs References Committee, 2012). Others maintain they did not ever sign the required paperwork. It appears that a culture of forced adoption prevailed in Australia, with associated stigma and stereotypes that silenced these parents for decades (O'Halloran, 2006; Kelly, 2005; The Senate Community Affairs References Committee, 2012).

Many mothers felt unable to speak about their hidden pregnancies, their treatment during traumatic birth experiences, and the coercion to sign. Their distress was viewed publicly as appropriate punishment for their immorality (Inglis, 1984; Shawyer, 1979). In addition, they were silenced about the trauma of being separated permanently from their babies. A mother who relinquished her child agreed "as an intrinsic part of consent, to become both anonymous and untraceable" (Inglis, 1984, p. 11). Often young, in personal crisis and vulnerable, many mothers were not informed of their legal rights to keep their babies. Rather, they were made to feel immoral, and deemed inadequate to parent (Inglis, 1984). In some cases single 
mothers were deliberately denied access to counselling prior to 'giving' consent (Australian Association of Social Workers [AASW], 2011).

In Australia, the enormous human toll of adoption began to be revealed during the 1980s when mothers broke the taboo of silence about their suffering and their involuntary separation from their children (Inglis, 1984). Emerging research documented their intense grief and the adverse emotional impacts of adoption that increased rather than decreased over time (Blanton \& Deschner, 1990; Condon, 1986; Inglis, 1984; Weinreb, 1991; Wells, 1993a, 1993b; Winkler \& Van Keppel, 1984). In many instances, fathers were discounted and blamed for corrupting innocent girls. However more recently, there has been a recognition of fathers grief as not dissimilar to mothers grief (Clapton, 2003, 2007; Coles, 2009). Clapton (2003) spoke of an enduring psychological attachment between the child and their biological father that is of significance to both, whether the father is present or absent, and even if he has never known the child. Like mothers, fathers grieve for their lost children.

Across decades in the mid-twentieth century, the accepted, positive narrative of closed adoption contained an array of powerful assumptions and social prescriptions that served to disenfranchise, exclude and render birth parents invisible and silent (Kelly, 2005). For example, unmarried mothers were labelled immoral, hence the need for secrecy so the child (and the mother) did not carry the social stigma. Further, it was proclaimed to be in the best interests of parents and babies that contact be severed immediately after the birth before any relationship had begun between them. It is now widely accepted that the mother/child bond begins in the womb (Lake, 1981; Lifton, 1994; Russell, 1996; Wirth, 2001). It was expected that mothers may grieve for a time but then must get on with their lives.

However, Simone (1996) found that mothers' grief was severe and prolonged, particularly in the absence of social recognition and empathy for the child lost to them, or any opportunity to speak or be heard. While it has been reported that many adoptees had positive family relationships with their adoptive families $\left(1^{\text {st }}\right.$ Author, 2010a; Marshall \& McDonald, 2001), ongoing mental health issues have been documented (Borczyskowski, Hjern, Lindblad, \& Vinnerljung, 2006; Condon, 1986; $1^{\text {st }}$ Author, 2008). According to Verrier (1993) the removal of a baby from their mother during the first moments after birth inflicts a 'primal wound' for the child 
characterised by an abiding sense of loss, a basic mistrust in life, anxiety, depression and difficulties in personal adult relationships.

In a study exploring links between adoption and suicide, $1^{\text {st }}$ Author (2008) concluded that the master narrative of 'unwanted' children placed voluntarily into closed adoptions co-opted many birth parents and adopted people to enact the accepted adoption story. In that study, parents and adoptees described a performance of accepted roles that provoked "despair and felt misrelation in a true sense of both their ontological self and correct biological relationships, resulting in mental ill health" (p. 8). From the 1980s, past damaging adoption practices began to be scrutinized and the dominant, social narrative that adoption benefited all parties has now been deconstructed. As noted, similarities to the Australian adoption story are evident in stories from the Stolen Generation, British child migrants and Forgotten Australians (Ekermann, et al., 2008; Humphreys, 1995). All of these children went missing from the lives of parents and loved ones, often without a trace.

Recently in Queensland (as similar to other states), the Child Protection Commission of Inquiry has canvassed adoption as a possible reform option for the long term care of children in the child protection system (Queensland Child Protection Commission of Inquiry, 2012). While it can be argued that this suggested reform is a reversion to past harmful practices (Hirst, 2013), a counter-argument also could be made that open adoption which is inclusive of birth parents, could be a viable alternative under extreme circumstances. Wherever possible, preserving biological links is paramount for both parents and children to avoid the preventable and an unnecessary trauma of 'missingness'.

\section{Missing persons, trauma and healing}

Every year in Australia, approximately 30,000 people are reported missing (Henderson, Henderson, \& Kiernan, 2000). They are perceived to be missing due to circumstances that include a person in hiding, runaways, soldiers missing in action, unknown suicides, stranger abductions, parental abductions, dementia, mental health issues, violent crimes including domestic and family violence, people who are homeless and wandering, and those who do not want to be located (Biehal, Mitchell \& Wade, 2003; Clark, 2007; Henderson, Henderson, \& Kiernan, 2000; Mitchell, 2003; Wayland, 2007). Only a small minority remain missing one month after their absence was reported. 
When someone goes missing unaccountably, the family left behind experiences the ambiguous loss of a person who is still psychologically present, but physically absent (Wayland, 2007; Boss, 1999a). Ambiguous loss has been described as the most difficult and devastating loss because it is indeterminate, and "the greater the ambiguity surrounding one's loss, the more difficult it is to master it and the greater one's depression, anxiety, and family conflict" (Boss, 1999a, pp. 56). In addition, the ambiguity forestalls the normal grieving process and people feel baffled, immobilised, grief stricken and unable to reorganise their lives.

When someone goes missing, families report a tumult of emotions including shock, fear, shame, guilt, desperation, embarrassment, frustration, anxiety, anguish, despair, sadness and helplessness (Hunter Institute of Mental Health [HIMH], 2001). This trauma is profoundly destabilising for the individuals and families concerned who feel overwhelmed and unable to resume what they previously experienced as normal functioning. These families' worldviews and beliefs about life are shattered and require substantial re-construction. The inexplicable loss compromises their sense of justice, and their faith in the general "good" of people, and they may feel a heightened sense that the world is no longer a safe place $(\mathrm{HIMH}, 2001, \mathrm{p} .23$; Missing People, 2012). Many people become preoccupied with thoughts about searching for the missing person (Missing People, 2012). Resolution occurs when the missing person either is found alive - the vast majority located or returning home within a month - or deceased (Wayland, 2007). In the interim, the task for families and those supporting them is to learn how to maintain uncertain hope, endure the "unending not knowing," and find some means of modulating the distress, trauma and suffering (HIMH, 2001; Missing People, 2012, p. 7; Clark, 2007).

For families of missing persons, particularly missing children, public empathy, caring and concern may help to buffer the harsh reality. Recommended strategies in the literature for professionals assisting such families include listening to their story, exploring ways of remembering and including the loved one, supporting the family to express their emotional responses, and creating a safe place where families can speak about their experiences (Wayland, 2007). The main goal of these interventions is to enable families to develop a tolerance for ambiguity, rather than looking to resolve what may be unresolvable. As reported in the literature, many people, including professional helpers, find it difficult to bear the helplessness of ambiguous loss, and unwittingly bring pressure on those who are grieving to find 
closure (Boss, Beaulieu, Wieling, Turner \& La Cruz, 2003). Instead, it is recommended that helpers demonstrate empathy and caring, build families' coping abilities and facilitate ways to minimise their stress $(\mathrm{HMIH}, 2001)$.

Prolonged, unresolved grief can be diagnosed as pathological because of a person's refusal to let go of the loved one (Boss, 1999b). However, in the case of missing family members, Boss (1999a), argues that the situation itself, and not the internal psychological state of a person, may prevent them from letting go, and that this situational barrier cannot be described as pathological because the force that precludes closure lies outside the person. This is an important distinction for helpers to make.

In the missing person's literature, the term 'frozen grief' recurs frequently. Ambiguous loss is described as "living with frozen grief" (Boss, 1999b, p. 4). Not knowing the location of the loved one prevents people from reorganising their lives and adjusting to the loss, so "the couple or family relationship freezes in place" (Boss, 1999a, p. 7; Clark, 2007). Examples include the grief patterns of families of military personnel who are missing in action, which often are assessed as stuck and maladaptive (Missing in Action Forum, n.d.). Similarly, families of those missing in New York after September 11 ${ }^{\text {th }}, 2001$ were described as being frozen in time because not knowing if a loved one is dead or alive "complicates grief, paralyses family processes, and prevents mourning and moving on" (Boss, et al., 2003, p. 456). In such circumstances, people who previously were healthy, strong, competent and resilient felt powerless and immobilised by ambiguous loss.

Fravel and Boss (1992), offer a case study of the Klein family to highlight the lived experience of ambiguous loss and a pathway to healing. In an unimaginable turn of events, Betty and Kenneth Klein's three sons aged 8, 6 and 4, went missing after walking to the park near their home. The boys were never found. Over time the Kleins went on to have four more sons and moved back to their hometown, recreating their lives within a supportive network of family and friends (Fravel \& Boss, 1992). A key strategy the Kleins employed to overcome their immobilising grief was the development of a personal healing theory, facilitated by community compassion that enabled them to balance hope with realism (Figley, 1988; Fravel \& Boss, 1992).

As described by Figley (1988), a 'healing theory' is an enabling process where each family member describes all facets of an unfolding traumatic event, including 
how and why they behaved as they did, to create a shared perception of the event, with reduced distortions and blame. According to Fravel and Boss (1992), the Kleins appeared to have accomplished this healing process. Contributing factors were their religious faith and raising their subsequent children, while a major factor from which they derived strength appeared to be the enormous outpouring of social support from their community (Fravel \& Boss, 1992). Social support is known to play a role in a person's ability to cope with loss, the perceived availability of that support being predictive of the extent of their coping ( $\mathrm{HIMH}, 2001$; Missing People, 2012).

\section{Parallels between adoption and missing persons}

While not diminishing the trauma of a reported missing child whose whereabouts are unknown and fears are held for their safety, the missing person lens can offer a useful framework for professional helpers (psychologists, social workers, counsellors and support workers) to gain increased insight into the ongoing thoughts, anxieties and fears faced by birth parents following adoption. It is acknowledged that there are obvious differences between missing persons and loss by adoption. In the former situation, someone disappears unexpectedly without a trace. Police and other services are informed and enlisted to search. Emergency supports are mobilised and there is usually strong public empathy for the plight of the family. In contrast, birth parents often perceived that the baby could be placed for adoption, with coercion in the case of forced adoptions. Supports may or may not have existed depending upon the era, and there may have been be very little, if any, public empathy for the parents because closed adoption required their silence and absence.

However, despite these differences, striking similarities exist between the scenarios of adoption and that of missing persons. Both events may occur because of a voluntary or an involuntary act as determined by others, yet the grief may be the same. Feelings of ambiguous loss develop because a loved child's whereabouts is unknown to the parents. The child is missing from their lives and their feelings of guilt, blame, grief, loss and hope cannot be reconciled because the person is presumed to be alive unless evidence to the contrary is revealed. The loved one is psychologically present but physically absent and there may be severe health and mental health consequences for the parents if the situation continues long-term (Boss, 1999a). Perhaps because of the unquestioned dominance of the adoption 
meta-narrative, these commonalities do not appear to have served to engender empathy for birth parents.

In a recent study by the $1^{\text {st }}$ Author (2010b), social work students' lack of empathy for birth parents was highlighted. In classroom-based research, second year students were asked to define empathy, articulate their empathy for four real life vignettes, and reflect on how they make sense of their own responses. One vignette featured a mother's story of coerced relinquishment of her baby. The author had speculated, incorrectly as it transpired, that the adoption narrative might evoke a high empathetic response given the changes in public sentiment concerning forced adoptions.

While students revealed a range of empathy from compassionate to dispassionate, minimal empathy for the adoption vignette was evident when compared across vignettes. Students' answers and reasoning about their minimal empathy cited a lack of similar experiences as an explanation for their lack of empathy. In addition, they made moral inferences about the mother's behaviour and her decision-making at the time of the adoption, and they demonstrated an apparent unwillingness to engage emotionally with the narrative. It is possible that normative expectations of ongoing motherhood that is breached by adoption could explain the lack of social empathy for birth mothers. $1^{\text {st }}$ Author (2010b) concluded that enactment of empathy may be contextual and may be influenced by entrenched social norms and moral judgements (Hoffman, 1982; Taylor \& White, 2006).

$1^{\text {st }}$ Author (2010b) recommended that social work educators needed to engage students more proactively in order to transform their definitional understanding of empathy into a mastery of deeper empathy, particularly for working effectively in adoption contexts. In an earlier study, Rutman, Strega, Callahan and Dominelli (2002, p. 151) reported somewhat similar findings of minimal empathy expressed by some professional helpers for young single mothers who did not fit their construction of "deserving" mothers. Equally, Hoffman (cited in Duan \& Hill, 1996, p. 264) identified that an empathiser's socialised perception of another individual's "innocence" may influence their empathic response.

\section{$2^{\text {nd }}$ authors' personal experience}

As noted, in the social exclusion of minority groups, it has been observed that metanarratives often function to limit, stereotype and exclude those individuals whose 
experiences fall outside the prescribed social norms (Meininger, 2010; Swartz, 1992). Past adoptions processes in Australia appear to reflect a master narrative of undeserving mothers who did not fit the social norms, and therefore had forsaken their rights to exist in a relationship with or grieve their 'relinquished' child. It was assumed that they would not suffer from the 'unending not knowing' about what happened to their child.

The power of this meta-narrative was brought home to the $2^{\text {nd }}$ Author when she disclosed her predicaments about adoption to family or friends. Even to those individuals with no personal experience or knowledge of adoption, it appeared obvious to them what was the morally correct or appropriate behaviour required of her as a birth mother, regardless of whether it was unjust or caused deep suffering. The repeated, unquestioned dominance of this mythology made it difficult for the $2^{\text {nd }}$ Author to think outside the imposed 'truth'.

The following accounts by the $2^{\text {nd }}$ Author, which include a dream, reflections and a journal entry, document some of her lived experience of the ongoing trauma of adoption, evoking clear parallels to a missing person scenario.

\section{Dream}

I am with my daughter and we are wandering around inside a big old house, a museum or some other public place. It is swarming with school children on an excursion. My daughter disappears, she has wandered off and I cannot find her. I search the place, room by room, becoming more frantic. Finally in tears and desperate, I approach the desk to ask for help. Sobbing, I try to get out the story and as I speak, a young girl quietly comes up beside me. I don't recognise her at first, something obscures her face, but then I see it is my daughter and I am flooded with relief. Outside a bureaucrat in a black suit makes a snide remark about me being a hysterical mother. I am furious and as I begin a tirade at him, I feel my strength drain away like water down a plughole. He turns and walks away.

My paranoia about losing my daughter, my second child after relinquishing my son to adoption, has been a recurring nightmare, both in sleep and wakefulness. An adoption worker once told me: "When you have lost a child, by whatever means, you know that losing a child is possible; you never forget that knowing." When my daughter began school, I was terrified that if I did not see her physically walk into the 
classroom, or if I waited for her out the front after school, she would go missing. Although I knew this was completely irrational, my fear persisted. On one memorable occasion when a good friend took both our daughters on an outing, I became filled with dread that my daughter would not return. By late afternoon, I had curled up on the couch, paralysed with terror. When my friend's car eventually pulled up out the front, I hugged my daughter to me as if her life had just been spared. These incidents are examples of countless others that occurred periodically as my daughter was growing up.

The dream occurred on the morning of my son's fifteenth birthday. His adoption at nearly twelve weeks old did not begin as a closed adoption. On the contrary, it began as an unconventional, semi-open arrangement in which I met his adoptive parents and they agreed to send me photos and information about him twice a year via the agency. For his first four and a half years, my grief and loss were softened by the reassurance of knowing that he was loved and thriving, and by being indirectly included in his life. Then the photos stopped coming. I was profoundly shocked to find out that the original agreement had been terminated and replaced with a closed adoption arrangement. During this ordeal and in the succeeding years, I experienced a desperation that pushed me to the brink of suicide. A chronic depression and frozen grief were my constant companions. A journal excerpt from this time expresses my state:

\section{June, 2002}

I feel profoundly disenfranchised. I am aware of the trauma, the grief, the loss, the emptiness...but it is all nullified...of no consequence, not deemed worthy of recognition. When my grief and loss are disenfranchised, this means I myself am disenfranchised. I have a son who is vitally important to me; yet I am discarded from his life. These experiences are the deepest expression of my spirit. When they are disenfranchised, it compounds my grief because it is frozen. Not only am I deprived of my legitimate connection with my son, but I am dispossessed of even my own responses to that loss.

During the early years of my son's life when I still had the reassurance of photos and news of him, I did not experience this trauma, dread and paranoia. The photos and information meant my continuity with him and his with me, and they 
showed me he that was loved and thriving, even though we were separated. When they stopped, in a very real sense, he went 'missing' and I experienced many of the features of ambiguous loss reported by families of missing persons.

For many years, until I began to search for my son as an adult, the episodic grief and trauma recurred at unpredictable intervals, triggered by random events. Very few people knew the story and those who did mostly accepted the closed adoption narrative without question. In that version, my role as a birth mother was to remain invisible and voiceless; I had relinquished my son so that meant I had forsaken any right to be included in his life. This was extremely isolating. Despite the injustice and trauma of my 'missing' son, there was very little support. What was notably absent was the empathy and community support extended to other mothers of missing children in non-adoption situations. Consequently, it was difficult to develop a meaningful personal healing theory as the Kleins had achieved, to ameliorate my stress.

\section{Discussion}

Many submissions to the Senate Inquiry urged the federal government to demonstrate international leadership (The Senate Community Affairs References Committee, 2012). As a result, a formal apology was delivered by the Prime Minister, Julia Gillard, on the 21st of March, 2013. There is hope for a national framework, guidelines, accredited training, and adoption grief counselling to be developed in consultation with affected stakeholders (parents, their extended families and adopted people). Clearly, past adoption practices and the associated meta-narratives have been damaging to birth parents, adoptees and their families. Parents were confronted with a system of institutionalised attitudes and practices that rendered them silent and invisible. The trauma and ambiguous loss described by families of missing persons may resonate with birth parents who have lived with frozen, disenfranchised grief and the torment of not knowing if they will ever see their missing child again.

As noted earlier in this article, in a study exploring the links between suicide and adoption, $1^{\text {st }}$ Author (2008) speculated that the accepted master narrative of voluntary, closed adoption co-opted the public, birth parents and adoptees to enact the accepted adoption story. In reporting those findings, $1^{\text {st }}$ Author identified that 
continuing the performance of the accepted roles provoked despair, while rejection of the accepted story and enactment of their own truth could assist healing. Initially, $2^{\text {nd }}$ Author found awakening to the fact that she was 'performing' this role with difficulty. Backed by formidable forces including legislation, policies, services, professional practices, and entrenched public perceptions, the powerful, exclusionary adoption meta-narrative was difficult to lay bare.

$1^{\text {st }}$ Author (2008) advocated that a pathway out of the grief and despair faced by birth parents was "through advancing personal agency, revealing the denied reality, claiming power, recognising the disconnectedness for the self of the prescribed 'performativity' and reconciling the self through the honouring of respectful, transparent, correct relations" (p. 8). The implementation of these suggestions proved highly effective for $2^{\text {nd }}$ Author, particularly the exercise of personal agency and resources, exposing the denied reality, and acting to restore respectful, correct relations.

For helpers supporting birth parents enduring ambiguous loss, the many strategies suggested for families of missing persons may be highly relevant. Professional workers may need to be critically reflective of their own levels of empathy and their own personal ambiguities or judgements ( $1^{\text {st }}$ Author, 2010b; Missing People, 2012). In addition, social work education needs to engage students more proactively in critical reflection to enable them to explore their assumptions and judgments in relation to adoption.

Naming the adoption experience as ambiguous loss could be another important step (Boss, et al., 2003). Using the analogy of missing persons, professional helpers can hear clients' stories, acknowledge their feelings of anxiety, fear and ambivalence, encourage reminiscence, and honour their resistance to closure as normal reactions (Missing People, 2012). Similarly, adopted people's grief for missing parents might be acknowledged in the same way. Normalising responses, reducing isolation, and facilitating empowerment may enable people to cease blaming themselves or other family members for what they have experienced (Boss et al., 2003). Providing deep empathy and a safe space for families to express the full depth and range of their emotions, including their sense of fear, guilt, community condemnation and enduring hope, is imperative. When stories are told, heard, and validated as legitimate, the 'frozenness' of their grief has a chance to thaw. 
Social exclusion is said to exist where persons or groups are not heard or valued as legitimate, deserving participants in a society and they are hindered from actioning their own personal agency and resources. In recognition of the power of meta-narratives to exclude, Meininger (2010) urged the generation of a more socially inclusive, replacement story. As noted earlier, the Klein family, whose three children went missing, found significant solace in the community, sorrow generated in response to their story. While the support they felt might not be illustrative of the experiences of all families of missing persons (Clark, 2006), the acceptance and inclusion of their story, and the individual, public and social empathy that it engendered, enabled them to activate a process of healing. Understanding birth parents' narratives through a 'missing persons' lens may help generate a replacement story, one that offers social inclusion to many families whose stories of missing loved ones are different from the norm.

\section{Conclusion}

Until recently, the grief and suffering of parents whose lives have been impacted by children missing through adoption has remained largely hidden from view, not unlike the missing children and adults they mourn. As established through the recent Senate Inquiry into forced adoption (The Senate Community Affairs References Committee, 2012), the lives of many birth parents and extended families have been dominated by experiences of trauma, grief and loss over missing children. Equally, adopted people may grieve 'missing parents'. It appears that the master-scripting of the adoption story has muted social empathy that otherwise might have recognised and supported birth parents' grief for a missing child. As a matter of justice, it is timely to increase empathy and social inclusion for a range of 'missing persons' stories to enable many grieving individuals and families to navigate a healing journey.

\section{References}

Australian Association of Social Workers [AASW]. (2011). Submission to the Senate Community Affairs Reference Committee into the Commonwealth contribution to former forced adoption policies and practices. Canberra City, ACT: Australian Association of Social Workers 
Askren, H., \& Bloom, K. (1999). Post-adoptive reactions of the relinquishing mother: A review. Journal of Obstetric, Gynaecological and Neonatal Nursing, 28, 395400.

Biehal, N., Mitchell, F.,\& Wade, J. (2003). Lost from view: Missing persons in the UK. Bristol: The Policy Press.

Blanton, T., \& Deschner, J. (1990). Biological mothers' grief: The post-adoptive experience in open versus confidential adoption. Child Welfare, 69, 525-535.

Borczyskowski, A. V., Hjern, A., Lindblad, F., \& Vinnerljung, B. (2006). Suicidal behaviour in national and international adult adoptees: A Swedish cohort study. Social Psychiatry \& Psychiatric Epidemiology, 41, 95-102. doi: 10.1007/s00127-005-0974-2

Boss, P. (1999a).Ambiguous loss: Learning to live with unresolved grief. Cambridge, Massachusetts: Harvard University Press.

Boss, P. (1999b). Ambiguous loss: Living with frozen grief. The Harvard Mental Health Letter, November, 1999, 4-6. Retrieved from http://www.impact.arq.org/doc/kennisbank/1000011020-1.pdf

Boss, P., Beaulieu, L., Wieling, E., Turner, W., \& La Cruz, S. (2003). Healing loss, ambiguity, and trauma: A community-based intervention with families of union workers missing after the 9/11 attack in New York City. Journal of Marital and Family Therapy, 29, 455-467. Retrieved from http://www.impactkenniscentrum.nl/doc/kennisbank/1000011021-1.pdf

Bourdieu, P. (1977). Cultural reproduction and social reproduction. In J. Karabel \& A. Halsey (Eds.), Power and Ideology in Education (pp. 487-511). New York: Oxford University Press.

Carabas, T., \& Harter, L. (2005). State-induced illness and forbidden stories: The role of storytelling in healing individual and social traumas in Romania. In $\mathrm{L}$. Harter, L. Japp, \& C. Beck (Eds.), Narratives, health and healing (pp. 149-169). New York: Taylor and Francis.

Chamberlain, S. (2011). Whispers on the wind: Social inclusion and the media. Journal of Social Inclusion, 2(2), 71-81.

Clark, J. (2007). Adult siblings of long-term missing people: Loss and 'unending not knowing'. Grief Matters: The Australian Journal of Grief and Bereavement, 10, 16-19. Retrieved from http://trove.nla.gov.au/work/3850337?q\&sort=holdings+desc \& $=13536$ 53496073\&versionld $=52241007$

Clark, J. (2006). Wanting to hope: The experiences of adult siblings of longterm missing people (Doctoral thesis). University of Queensland, Queensland.

Clapton, G. (2003). Birth fathers and their adoption experiences. London: Jessica Kingsley.

Cole, C. (Ed.). (2008). Releasing the past: Mothers' stories of their stolen babies. Yagoona, N.S.W: SaskoVeljanov.

Coles, G. (2009). Why birth fathers matter. Australian Journal of Adoption, 1, 1-6. Retrieved from http://www.nla.gov.au/openpublish/index.php/aja/article/viewFile/1542/1847

Commonwealth of Australia, DEEWR. (2009). Social inclusion: The origins, meaning, definition and economic implications of the concept social inclusion/exclusion. Canberra: Department of Education, Employment and Workplace Relations. 
Condon, J. (1986). Psychological disability in women who relinquish a baby for adoption. The Medical Journal of Australia, 144, 117-119.

Duan, C., \& Hill, C. (1996). The state of empathy research. Journal of Counseling Psychology, 43(3), 261-274.

Eckermann, A., Dowd, T., Chong, E., Nixon, L., Gray, R., \& Johnson, S. (2006). BinanGoonj: Bridging cultures in Aboriginal health. New South Wales: Elsevier Australia.

Edwards, C., \& Read, P. (1989). The lost children. Sydney: Doubleday.

Figley, C. (1988). A five phase treatment of post traumatic stress disorder in families.Journal of Traumatic Stress, 1(1), 127-141.

Fravel, D. L., \& Boss, P. G. (1992). An in-depth interview with the parents of missing children.In J. F. Gilgun, K. Daly, \& G. Handel (Eds.), Qualitative methods in family research (pp. 126-145). Newbury Park, CA: Sage.

$1^{\text {st }}$ Author [Gair, S.]. (2008). The psychic disequilibrium of adoption: Stories exploring links between adoption and suicidal thoughts and actions. Australian e-Journal for the Advancement of Mental Health, 7, 1-10. Retrieved from www.auseinet.com/journal/vol7iss3/gair.pdf

$1^{\text {st }}$ Author [Gair, S.]. (2010a). A different road to mothering. VDM.

$1^{\text {st }}$ Author [Gair, S.]. (2010b). Social work students' thoughts on their (in)ability to empathise with a birth mother's story. Adoption and Fostering, 34, 39-49.

$1^{\text {st }} \& 2^{\text {nd }}$ Authors [Gair, S., \& Moloney, S.]. (2013). Unspeakable stories: When counter narratives are deemed unacceptable for publication. Qualitative Research Journal, 13(1) 49-61.

Hancox, D. (2011). Stories with impact: The potential of storytelling to contribute to cultural research and social inclusion. Media and Culture Journal, 14(6). Retrieved from http://journal.mediaculture.org.au/index.php/mcjournal/article/viewArticle/439

Henderson, M., \& Henderson, P. (1998). Missing people: Issues for the Australian community. Canberra: Commonwealth of Australia

Henderson, M., Henderson, P., \& Kiernan, C. (2000). Missing Persons: Incidence, issues, and impacts (No. 144). Canberra: Australian Institute of Criminology.

Higgins, D. (2010). Impact of past adoption practices: Summary of key issues from Australian research. A report to the Australian Government Department of Families, Housing, Community Services and Indigenous Affairs.Canberra: Australian Institute of Family Studies.

Hirst, J. (2013, February 20). Best chance for addicts' kids lies in adoption. The Australian, p. 12.

Hoffman, M. (1982). Development of prosocial motivation: Empathy and guilt. In N. Eisenberg (Ed.), The development of prosocial behavior (pp 281-311). New York: Academic Press.

Human Rights and Equal Opportunity Commission. (1997). Bringing them home: A guide to the findings and recommendations of the National Inquiry into the Separation of Aboriginal and Torres Strait Islander Children from Their Families. Sydney: Human Rights and Equal Opportunity Commission. Retrieved from http://www.austlii.edu.au/au/special/rsjproject/rsjlibrary/hreoc/

Humphreys, M. (1995). Empty cradles. London: Corgi Books. 
Hunter Institute of Mental Health. (2001). Best practice in counselling models relevant to families and friends of missing persons. Sydney: NSW Attorney Generals Department. Retrieved from http://www.missingpersons.lawlink.nsw.gov.au/agdbasev7 wr/missingpersons/d ocuments/pdf/fmp08 hope-that-hurts.pdf

Inglis, K. (1984). Living mistakes. Sydney: Allen and Unwin.

James, M., Anderson, J., \& Putt, J. (2008).Missing persons in Australia: Research and Public Policy (Series No. 86). Canberra: Australian Institute of Criminology.

Kelly, R. (2005). Motherhood silenced. Dublin: The Liffey Press.

Lake, F. (1981). Tight corners in pastoral counselling. London: Darton, Longman and Todd.

Lareau, A., \& McNamara Horvat, E. (1999). Moments of social inclusion and exclusion: Race, class and cultural capital in family-school relationships. Sociology of Education, 72(1), 37-53.

Lifton, J. (1994). Journey of the adopted self. New York: Basic Books.

McNiece, M. (2006). The experience of Australian relinquishing mothers in open adoption: Contact, grief and psychological adjustment (Doctoral dissertation, Victoria University). Retrieved from http://vuir.vu.edu.au/16084/1/MCNIECE 2006compressed.pdf

Marshall, A., \& McDonald, M. (2001). The many-sided triangle. Melbourne: University Press.

Meininger, H. P. (2010). Connecting stories: A narrative approach of social inclusion of persons with intellectual disability. ALTER, European Journal of Disability Research, 4, 190-202.

Missing in Action Forum. (n.d.). Encyclopedia of death and dying. Retrieved from http://www.deathreference.com/Me-Nu/Missing-in-Action.html\#b

Missing People. (2012). An uncertain hope: Missing people's overview of the theory, research and learning about how it feels for families when a loved one goes missing. London: Missing People Charity.

Mitchell, F. (2003). Can I come home? The experience of young runaways contacting the Message Home Helpline. Child and Family Social Work, 8, 3-11.

O' Halloran, K. (2006). The politics of adoption. Netherlands: Springer.

Opotow, S. (1990). Moral exclusion and injustice: An introduction. Journal of Social Issues, 46, 1-20.

Payne, M. (1995). Understanding 'going missing': Issues for social work and social services. British Journal of Social Work, 25, 333-348.

Queensland Child Protection Commission of Inquiry: Options for reform. (2012). Queensland: Queensland Child Protection Commission of Inquiry.

Russell, M. (1996). Adoption wisdom: A guide to the issues and feelings of adoption. Los Angeles: Broken Branch Productions.

Rutman, D., Strega, S., Callahan, M., \& Dominelli, L. (2002).'Undeserving' mothers? Practitioners' experiences working with young mothers in/from care. Child and Family Social Work, 7, 149-159.

Shawyer, J. (1979). Death by adoption. Auckland: Cicada Press.

Simone, M. (1996). Birth mother loss: Contributing factors to unresolved grief. Clinical Social Work Journal, 24, 65-76.

Swartz, E. (1992). Emancipating narratives: Rewriting the master scripts in the school curriculum. Journal of Negro Education, 61, 341-355.

Taylor, C., \& White, S. (2006). Knowledge and reasoning in social work: Educating for humane judgment. British Journal of Social Work, 36, 937-954. 
The Senate Community Affairs References Committee. (2012). Commonwealth contribution to former forced adoption policies and practices. Canberra: Commonwealth of Australia.

Verrier, N. (1993). The primal wound. Baltimore: Gateway Press.

Watson, L., \& Granvold, D. (2008). Whose baby is it? Modern influence in adoption practices in the United States. Personal Construct Theory and Practice, 5, 111118.

Wayland, S. (2007). Supporting those who are left behind: A counselling framework to support families of missing persons. National Missing Persons Coordination Centre, Australian Federal Police. Canberra: Commonwealth of Australia.

Weinreb, M. (1991). The psychological experience of women who surrender babies for adoption. Dissertation Abstracts International, 52, (6-A).

Wells, S. (1993a). Post-traumatic stress disorder in birthmothers. Adoption and Fostering, 17, 30-32.

Wells, S. (1993b). What do birthmothers want? Adoption and Fostering, 17, 22-26.

Winkler, R., \& Van Keppel, M. (1984). Relinquishing mothers in adoption: Their longterm adjustment [Monograph no. 3]. Melbourne: Melbourne Institute of Family Studies.

Wirth, F. (2001). Prenatal parenting. New York: Regan Books.

\section{Biographical Notes}

Dr Susan Gair is a senior lecturer and scholar in the Department of Social Work and Human Services at James Cook University. She has more than two decades of teaching, research, and practice experience focused on enacting her commitment towards the advancement of social justice, reconciliation, and improved social policy, social work practice and social work education. One primary area of her focus has been adoption practice.

Dr Sharon Moloney is a women's health practitioner, therapist and researcher. She has a private practice in Townsville working with couples and individual clients on a range of reproductive and other issues. Her doctoral research explored Australian women's experiences of menstruation and birth as spiritual phenomena. 